\title{
13. Accountability in the Governance of Global Change
}

\section{Brown \& M. Scobie}

\subsection{Introduction}

The transformation of the Earth System through human activity, and the further transformations required to ensure future sustainability, pose huge governance challenges (Foley et al., 2005; Reid et al., 2010). These challenges can complicate and overshadow efforts to achieve accountability, and may even require their wholesale reconceptualisation (Lövbrand, Stripple and Wiman, 2009; Biermann et al., 2012). Understanding the emerging pressures and forms of accountability under rapid global change is therefore a crucial task for earth systems governance research (Papadopoulos, 2007; Biermann and Gupta, 2011).

While the scale of many current governance challenges is new, responses can build on decades of research into accountability (Biermann and Gupta, 2011). In doing so, they inherit a number of perspectives and open debates. Of particular relevance are discussions about the value and function of accountability, whether as an independent normative property of governance systems or as an interacting element with benefits and trade-offs for others (Blair, 2000; Papadopoulos, 2003; Steffek and Ferretti, 2009). Recent research also emphasizes the dynamism of accountability as a theoretical and practical construct, and of its relationships with governance legitimacy and effectiveness (Bovaird, 2005; Papadopoulos, 2007; Bovens, Schillemans and Hart, 2008). In 2009, accountability was one of the five analytical problems identified by the Earth System Governance (ESG) Science Plan (Biermann et al., 2009), in which accountability was linked to agency and legitimacy. The Plan emphasized that issues related to accountability have profound policy implications for governing earth system transformations, and invited an analysis of the nature of accountability in democracy theorisations and accountability's relevance for institutional effectiveness.

This chapter analyses the extent to which these issues have been explored in earth systems governance research over the last ten years, using articles from the ESG 'Agency Harvest' database and other related research. Particular attention is paid to the conceptual, theoretical and empirical perspectives of published papers. This is not intended to provide an exhaustive overview of recent research but to highlight the most noteworthy trends in the literature, picking out current themes, gaps and potential future directions. In particular, we focus on frequently researched issues related to how accountability develops and affects the success of earth system governance, and its relationship to legitimacy between governance actors. 


\subsection{Conceptualising Accountability}

Accountability can be defined as "the legal obligation to respect the legitimate interests of others affected by decisions, programs, and interventions" (Considine, 2002) or less formally as "the willingness to accept responsibility or to account for one's actions" (Biermann and Gupta, 2011). These widely adopted conceptualisations identify accountability as a key aspect of earth system governance with respect to transformations that promote sustainable development. As such, research into the sources, mechanisms, forms and effects of accountability is of clear importance (Biermann et al., 2009).

Particularly important are the theoretical and normative foundations of accountability. Increasingly, these foundations are required to support a shifting load, with traditional forms of accountability losing relevance under both increasingly international and increasingly interactive forms of governance (Torfing et al., 2012; Brink and Wamsler, 2018; Held, 1999). Global challenges, and political responses to them, raise qualitatively novel issues of accountability; for instance concerning the democratic rights of southern and developing states, or of individual citizens, within globalised systems of knowledge and governance (Held, 1991; Miller, 2007; South Centre, 1997; Mason, 2008). These issues are especially pertinent given disparities in resources, representation and power between actors. Several authors have suggested that new conceptualisations of accountability are required in this context, to deal with new modes of authority exercised by non-state actors (Bernstein 2004) (Dingwerth and Pattberg 2009, Dingwerth 2007), new relationships between accountability, legitimacy and transparency (Florini 2007), and new relationships between power, authority and influence (Willer, Lovaglia, and Markovsky 1997). Underpinning many of these issues are changes in the extent and nature of agency in earth systems governance, both in terms of actors involved and the extent of agency available to those actors (Biermann and Gupta, 2011).

Beyond its theoretical underpinnings, it is also necessary to understand the practical or structural forms of accountability that are most relevant to earth systems governance. For example, financial support has long been used to increase the attendance of civil society groups, representatives of labour movements and developing states at decision making forums (Spiro 1995, 1988). Other proposals have included a Forum of Civil Society within the United Nations and a global parliamentarian assembly (Carlsson et al. 1995). As these examples suggest, the continuing diversification and internationalisation of governance systems has made architecture a key factor in accountability (Papadopoulos, 2003; Radaelli, 2003). Architecture often controls access and allocation across scales, structures and forums of governance. Potential steps to increase the scope of accountability in these settings include performance measurement and sanctions, knowledge dissemination and efforts to extend agency itself (Miller, 2007; Gupta, 2008; Dryzek and Stevenson, 2011). Ultimately, these steps also determine the legitimacy of resulting governance arrangements (Biermann and Gupta, 2011).

In the following sections, we use the Agency Harvesting database (systematic review) and other relevant literature (non-systematic review) to examine the extent to which these major theoretical and practical questions of accountability have been addressed, and go on to draw tentative conclusions about emerging conceptualisations of accountability and areas requiring future attention. 


\subsection{Existing Agency-Accountability Research}

\subsubsection{Coverage of Literature}

Using the ESG Agency Harvesting project database of 322 articles to give a representative overview of the field, we found that 90 articles $(28 \%)$ addressed questions of accountability in some way. These articles were reviewed in detail to ascertain dominant foci in terms of research questions, theoretical or methodological approaches, geographical coverage and types of actor. Overall, the number of articles steadily increased during the period 2008-2016, suggesting a growing prominence of accountability in earth system governance research. These studies were also found to have a largely global distribution (with Europe and Asia particularly well-represented), either focusing explicitly on global-scale governance (25 papers), or covering diverse areas between them. Nineteen articles focused on national or smaller scales, while 15 carried out international comparisons (eight of which were cross-continental).

Across geographies, the single most commonly studied agent type was states or national governments, which were included in 40 of the 90 articles analysed (Figure 13.1). In the great majority of these studies (all but two), relationships between these agents and others at smaller and/or larger geographical extents were the focus of study, with good representation of most other agent types. Particularly often included were issues of accountability involving state-IGO links. Conversely, individual agents were rarely included in studies, and only two studies focused on stateindividual relationships. Civil society agents were more often considered, as were intermediate-scale businesses, partnerships and networks, but sub-national governments were the second-least studied type, included in only 13 papers. The representation of different agent types did not vary clearly through time, except in the case of individual agents, which were included more commonly towards the end of the reviewed period (2012-2016).

Many studies considered issues related to accountability in the key global change topics of climate change mitigation or adaptation (37 papers in total, $41 \%$ of the papers analysed). Aside from these, frequently studied issues related to fresh water (10 studies), forests ( 8 studies) or biodiversity (6 studies). These issues were generally investigated through case studies, with 49 papers utilising this approach, far more than any other method. Quantitative analysis (8 papers), institutional analysis (6 papers) and descriptive analysis (5 papers) were also relatively common, but other approaches (including for example literature review, interviews or concept framing) were rarely used. This imbalance indicates a strongly empirical focus in the papers analysed, with conceptual and theoretical work being rare. Nevertheless, all of the papers did identify a theoretical basis, even where they did not attempt to contribute to its development. By far the most common of these was legitimacy theory, which was adopted by 31 papers, and agency theory, which was adopted by 19. This appears to indicate widespread acceptance of a relationship between accountability and legitimacy (as reflected in the ESG Science Plan), with a potential shortage of critical reflection on the nature of this relationship. The majority of studies (60 studies, or $66 \%$ of the total) also considered the issue of Architecture and how it relates to accountability. The problem of Allocation and Access was included in a substantial minority (19\%) of papers, while Adaptiveness was only included rarely (11\%), despite the strong focus on climate change adaptation. Overall, the literature on accountability appears well-embedded in broader earth system governance and social-scientific debates, albeit with some clearly predominant foci (particularly on legitimacy and power) that may overshadow novel or divergent conceptualisations. 


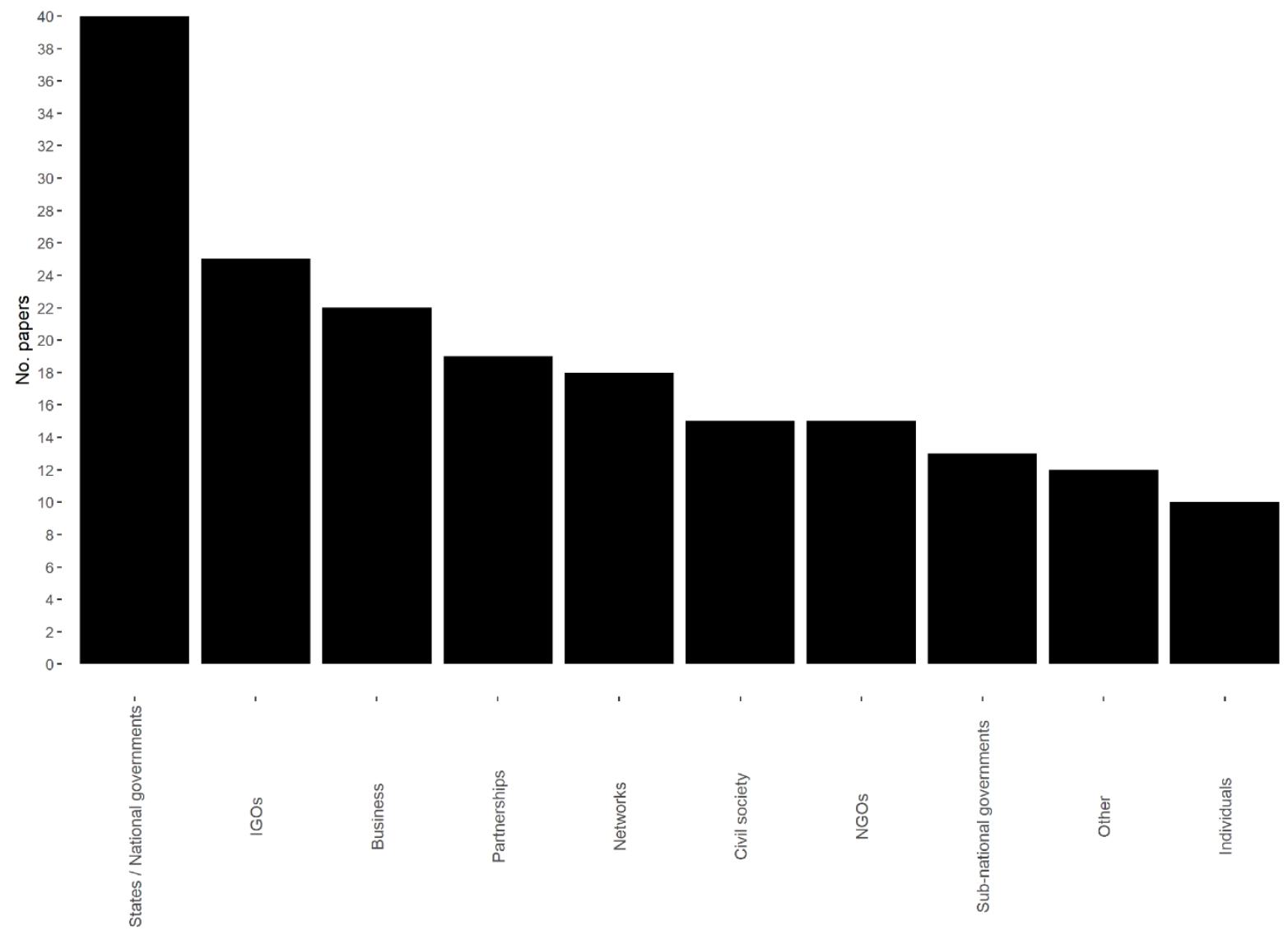

Figure 13.1 Types of agents included in studies contained in the ESG Agency Harvest database

\subsubsection{Conceptual Findings}

Within and beyond the literature described above, a number of conceptual developments are apparent in accountability research. For instance, accountability has been prominently used to refer to objective setting and compliance enforcing as part of the power relationships of global environmental governance (Gordon 2016). In this sense, accountability can be understood as a set of rules and procedures that outline who has the right to make decisions, and how they can be held accountable for those decisions (Chan and Pattberg 2008, Scobie 2017). A linked development is the conceptualisation of legitimacy as the extent to which actors with political power (agency) are governed by valid rules and shared understandings, as well as the extent to which stakeholders are the source of authority and consent to the structure of the governance system (Gellers 2016). Actors exercise agency in accountability by their right to hold others to a recognised set of standards (normative accountability), to determine how they have fulfilled their responsibilities (decision accountability) and to impose sanctions for failures (behavioral accountability) (Grant and Keohane 2005; Jamali 2010; Gilbert et al 2011).

Crucially, the question of accountability by and to whom (the relational accountability nexus) (Biermann and Gupta 2011) has been the basis of all the reflection on accountability and legitimacy in the different areas of governance research over the last decade. This includes accountability to citizens, especially affected groups, cities, markets, funding and development agencies, civil society, member states in governance regimes, the media, the judiciary, and government environmental agencies (in the case of ElAs), amongst others (Kolhoff et al. 2016; Gordon 2016). Many studies suggest that the conceptual breadth of accountability has, and continues to, expand across actors of these and other types as governance challenges prompt more actors to seek agency of their own and accountability of others (e.g. Considine 2002, Scherer et al 2006, Bäckstrand 2008). This 
expansion, in turn, necessitates new practical forms of accountability (see below), and new concepts that allow for novel, fluid relationships between governing and governed. These developments may have been hampered by the focus on national-level and other 'established' agents in the recent literature (see Section 10.3.1).

The expansion of the range of actors involved in earth systems governance has, nevertheless, prompted consideration of rationales of accountability between different actors. For example, Kramarz and Park (2016) refer to a public, private and voluntary logic of accountability to describe public responsibility, private motivations, or community or collective good motivations. Actors may also be driven by internal logics of accountability (oriented towards those within the system or direct stakeholders) or by external logics (oriented to those actors outside the system or external stakeholders) (Keohane 2003; Bäckstrand 2008). It is notable that these rationales implicitly or explicitly link accountability with legitimacy, inclusiveness (Dingwerth 2005), democracy, democratic legitimacy (Fuchs, Kalfagianni, and Havinga 2011) and representativeness, impartiality, empowerment, deliberativeness, lawfulness (Leach 2013, Leach 2006), human rights (Obani and Gupta 2016), distributive justice (Okereke and Coventry 2016) and transparency (Kramarz 2016, Gupta 2010). Not all of these links are clear, however, with the strength and direction of effects both subject to ongoing debate (Jamali 2010, Few, Brown \& Tompkins 2011, Papadopoulos 2014). These debates suggest that complex interactions between accountability and other facets of governance exist, both in theory and practice, with outcomes potentially differing widely in different governance systems and contexts (Bovens 2014).

Conceputalisations of accountability have therefore been notably fluid over recent years, and while they have expanded into several new areas they have crystalised in relatively few. This is perhaps most apparent in ongoing debates about the role and value of accountability in evolving governance settings, with different conceptualisations underpinning different assessments (as well as different ultimate implementations). Many papers acknowledge a democratic deficit caused by inadequate representative participation and accountability in global environmental governance, and see the solution as one of greater involvement of stakeholders in 'collaborative', 'networked' or 'interactive' governance (Jedd and Bixler, 2015; Torfing et al., 2012; Gellers 2016). Others, in contrast, suggest that such forms of governance risk embedding existing hierarchies and obscuring power dynamics, making outcomes less effective and even less democratic (Steffek and Ferretti, 2009; Papadopoulos, 2014; Papadopoulos, 2007). Fundamentally distinct ideas of what accountability can and should be are suggested by these arguments, demonstrating that further conceptual development - or at least clarification - remains necessary.

\subsubsection{Practical Findings}

The broad but partly unsettled conceptual nature of accountability is mirrored in practical attempts to increase it, which are growing in number but not necessarily in success. As our literature review showed, case studies are a major focus of research into accountability, providing considerably more evidence about implementation than about basic conceptualisation. However, many governance arrangements still tend to underrepresent local stakeholders and weaker groups in particular, limiting their utility as exemplars (e.g. Werners et al. 2009, Gulbrandsen and Auld 2016, Clare, Krogman, and Caine 2013). Accountability has been found to be particularly lacking in governance of climate change adaptation (Mees and Driessen, 2018). 
Networked or interactive governance has recently gained prominence as a potential solution to difficulties of accountability in the era of global change (Jedd and Bixler, 2015; Torfing et al., 2012). By formally including stakeholders from more diverse groups and levels, this mode of governance has been posited to increase democracy and legitimacy, but concerns have also been raised that existing hierarchical structures may become 'locked in', with illusory inclusivity actually reducing genuine democratic accountability (Papadopoulos, 2014). This has been identified as a factor for the environmental groups that have begun to separate themselves from the Marine Stewardship Council private certification agency (Gulbrandsen and Auld 2016), and the public private partnerships used by the World Bank for biodiversity conservation (Kramarz and Momani 2013). Despite the goal of increasing inclusiveness and empowerment in these institutional arrangements, they were more often than not unable to achieve democratic governance. Furthermore, even where successful, more inclusive forms of governance may be more suited to promoting mutual understanding and learning among stakeholders than tackling urgent but complex issues such as climate change, which might require bold, technical and often controversial responses (Baird et al., 2014; Papadopoulos, 2003; Rietveld et al., 2013). This basic tension between inclusivity and effectiveness is clearly unresolved in the field of climate change governance at least, with the literature suggesting that the necessary knowledge, motivation and mechanisms to increase both facets are lacking (Steffek and Ferretti, 2009; Brink and Wamsler, 2018; Vink, Dewulf and Termeer, 2013; Considine, 2002; Few, Brown and Tompkins, 2011).

Given these challenges, a substantial focus of recent research has been specific tools that can increase accountability and allow some actors to hold others responsible for their actions (Gordon 2016, Kramarz and Park 2016). These tools include certification, public participation (Jodoin, Duyck, and Lofts 2015), performance monitoring and self-reporting, stakeholder partnerships (Scobie 2017), cooperative initiatives between state and non-state actors (Widerberg and Stripple 2016), or future scenario planning and foresight practices with social actors (Kunseler et al. 2015). The spread of such practices represents a success in itself, and they have been found to result in meaningful improvement in the reach of both agency and accountability. However, widespread shortcomings have also been reported, often with respect to the adoption of particular practices providing an impression of accountability while granting little or no real agency to monitor or alter governance systems (Jamali 2010, Behnam \& MacLean 2011).

Accountability is therefore also facilitated by independent monitoring of dispute resolution mechanisms and participatory monitoring of environmental activities (Dunlop and Corbera 2016). Some studies of local natural resource management found trust-building between stakeholders and the incorporation of local ecological knowledge helpful for accountability and for resolving conservation conflicts (Young et al. 2016). Stakeholder partnerships have been found to help legitimise the operations of firms, increase positive exposure in the media, improve their reputation, build knowledge, strengthen relationships, increase "moral capital" (den Hond, de Bakker, and Doh 2012), their "social license to operate" (Gunningham, Kagan Robert, and Thornton 2006) and reduce their reputational risks (Godfrey Paul, Merrill Craig, and Hansen Jared 2008).

Nevertheless, it is unclear whether these collaborative processes truly facilitate legitimacy (Clare, Krogman, and Caine 2013), particularly when powerful actors can operate outside collaborative relationships to achieve their goals. Successful collaboration is premised inter alia on adequate incentives for participation, small imbalances in power and resources, and supportive leadership 
that can help deepen trust and shared understandings (Ansell and Gash 2008). In practice, however, local stakeholders enter these relationships with considerably less knowledge or access to knowledge, power and resources, again making these processes ill equipped for accountability. Indeed, accountability through stakeholder participation in local level institutions depends upon the stakeholders' capacity to act, access to resources (including knowledge, finance and time (Thaler and Leuin-Keitel 2016)) and in rural sectors upon the socio-economic characteristics of local populations (lower levels of education, authoritativeness of local tribal leaders and corruption made some local populations particularly vulnerable to land acquisition investors in Sierra Leone, for example (Yengoh et al. 2016)).

These difficulties are amplified in international governance systems, where even the forms of legitimacy and accountability in national democratic systems are lacking. At this scale, studies have identified relatively few mechanisms for increasing accountability. Crowdsourcing among global civil society allows for greater participation by a wide range of civil society actors, effectively giving them agency in governance and improving accountability. Unfortunately, this method may not necessarily be democratic or legitimate since crowdsourcing that depends on technology is limited by the inequitable "digital divide" in favor of developed states' civil societies. Crowdsourcing will facilitate accountability if democratic designs focus on multiple forms of outreach to allow balanced participation among stakeholders (Gellers 2016). At the global scale, press conferences at international negotiations (as for example in climate negotiations) could increase transparency and contribute to accountability, although they may also allow powerful states to wield undue influence (Betzold, Bernauer, and Koubi 2016). The widespread use of international accountability standards provides another example, but one in which agency is largely situated with the organisations adopting those standards, shielding them from meaningful oversight with potentially counterproductive consequences (Rasche 2009, Behnam \& MacLean 2011). Similar findings have been made in political, managerial and financial research, with agency often found to reside with those supposedly subject to accountability, severely limiting the efficacy of that accountability (Broadbent \& Laughlin 2003, Demirag, Dubnick \& Khadaroo 2004, Asenova \& Beck 2010).

Notwithstanding the limited number and success of methods to promote accountability, the literature suggests that improvements risk becoming counterproductive, and that accountability should not necessarily be an end in itself for agents of earth system governance. Often efforts to improve accountability focus on performance and compliance monitoring that may lead actors to lose sight of the environmental problems they were designed to redress (Kramarz and Park 2016, Fuchs, Kalfagianni, and Havinga 2011), or to apply accountability only in the latter part of the policy cycle, leaving policy formation and institutional design cycles without crucial inputs from stakeholders (Chan and Pattberg 2008) (Gulbrandsen 2008). This has been a feature of conservation programs that have led to the displacement of resource-dependent communities, for example (Mac Chapin 2004). More fundamentally, increased accountability, however it is achieved, may be to the detriment of flexibility, legitimacy and effectiveness, particularly where it operates on policy implementation as well as planning (Mees and Driessen, 2018). In these cases, efforts to increase accountability have often been found to reduce the scope for democratic alteration of implemented actions, either because they favour dialogue over decisive control, or because they replace genuine transparency and control (Papadopoulos 2014; Steffek and Ferretti, 2009; Behnam \& MacLean 2011). They can also reduce effectiveness where accountability is promoted in the absence of 
mechanisms to inform actors about governance topics and initiatives (i.e. where agency and accountability outstrips knowledge) (Adserà et al. 2003).

\subsection{Future Research Directions}

Given the uncertainties about the nature and effects of accountability in earth systems governance, a number of promising future research directions are apparent. Research published over the last decade does provide a broad evidence base that particularly addresses the development of accountability in specific governance settings. These often relate to accountability at the level of states or national governments, and in their relationships with a range of other agents (especially businesses and IGOs). Beyond these frequently studied areas, priorities for future research might include those listed below (several of which are considered in literature outside the earth systems governance field, such as business ethics or international relations, meaning that they could be pursued effectively through cross-disciplinary research; Falkner 2003, Jamali 2010, Behnam \& MacLean 2011).

Accountability at and between extremes of governance scale: Accountability at and between individual, sub-state and international scales has been relatively rarely studied (Steffek, 2010). This topic may justify more attention given the international nature of many governance initiatives, and their dependency upon buy-in, action and, ultimately, accountability of agents from individual to societal levels (Miller, 2007).

Accountability in practical climate change mitigation and adaptation: Climate change (mitigation and adaptation) are very often studied, being the dominant topics in literature published over the last decade. However, their treatment is often abstract and not related to specific practices, issues or changes. This suggests substantial scope for engaging with particular instances of mitigation or adaptation and the distribution of their relationships with agency and accountability (e.g. Bäckstrand 2008, Bache et al. 2015).

Different, general perspectives on accountability: In contrast to the often generic approach to climate-related issues, studies of agency and accountability have an overall tendency to rely on case studies, with relatively few taking theoretical or conceptual approaches. Furthermore, while theoretical foundations were identified in all the reviewed papers, there was relatively limited diversity in the theories used, with theories of legitimacy and agency being strongly dominant. While this suggests that relationships between agency, accountability and legitimacy are well-established, future studies that include a wider diversity of perspectives would have clear value in contributing to more fundamental knowledge of accountability.

Evolving relationships between accountability and other issues of agency: The relationships between governance architecture and accountability is well-studied, providing a substantial body of knowledge about how different agents create and affect accountability. However, much of this research relates to relatively static systems, with little research having been conducted into adaptiveness of accountability in particular. This stands in stark contrast to the volume of work on adaptation as a process of agency, and suggests limited understandings of how accountability, and architectures that support it, themselves respond to changing contexts. This lack of knowledge may be exacerbated by concurrent changes in allocation and access, both of which are relatively under- 
studied in the literature on accountability. Also neglected to date are links between knowledge (a key facet of agency) and accountability, once again implying scope for further research into the dynamics of accountability in evolving governance systems.

Positive vs. normative accounts: In general, the literature confirms the conceptual risk of treating accountability as a fundamentally normative characteristic. The foci of recent research are usually on identifying accountability and the circumstances that support it, rather than exploring its changing role in earth system governance and relationships to other outcomes, including the range of consequences that forms and degrees of accountability can have for other normative outcomes (Steffek and Ferretti, 2009; Papadopoulos 2007). Research that aims to redress this balance could potentially offer important new insights into relationships (both positive and negative) between accountability of different agents, at different scales, and in different governance settings.

\subsection{Conclusions}

Accountability is a frequently studied concept in the ESG literature. Conceptual and empirical definitions have to some extent converged towards an understanding of accountability as a product of the rules by which agency is permitted to, and later defined as the responsibility of, particular actors. To a large extent, definitions of this sort have been normative in nature, and a large proportion of the literature has been dedicated to identifying governance systems and structures within which accountability is maximised. This may have undesirable consequences for our understanding of accountability as an embedded characteristic of governance systems, subject to complex interactions with other characteristics that may or may not be valued in their own right. Furthermore, studies of this kind have largely taken place in the absence of more fundamental explorations of accountability as an evolving property of earth system governance, and with limited development of underlying theory or concepts. This remains a constraint on our understanding of the impact of accountability on earth system transformations, or indeed their impact on it.

Nevertheless, we found that the research reflected the growing concern for systems of accountability, particularly for state agents, but also for non-state actors, including networks, businesses and, to a limited extent, individuals. Similarly 'accountability to whom' has been increasingly addressed as the heretofore disempowered - from marginalised groups to the biosphere - are given increasing prominence. Finally, many studies recognised the multiple forms and effects of accountability and their relationships to power. Accountability, by its presence or absence, has had profound impacts on the effectiveness of governance, and is a key consideration for attempts to stimulate earth system transformations. Future research must enable us to ascertain how accountability might change, and how it is required to change, along with governance structures and the earth system itself.

The novel, global nature of these challenges provides a strong link between earth system governance research and other fields. Questions of agency and accountability are widely considered in literature on climate change mitigation and adaptation, business and international relations, amongst others. The relationships between actors involved in responding to global change are crucial to the success of those responses, and understanding how such relationships can best be shaped and utilised represents a major contribution of earth systems governance research. 


\section{References}

Adsera, A., Boix, C., \& Payne, M. (2003). Are you being served? Political accountability and quality of government. The Journal of Law, Economics, and Organization, 19(2), 445-490

Ansell, Chris, and Alison Gash. 2008. "Collaborative Governance in Theory and Practice." Journal of Public Administration Research and Theory 18 (4):543-571. doi: 10.1093/jopart/mum032.

Asenova D, Beck M (2010) Crucial silences: When accountability met PFI and finance capital. Crit Perspect Account 21:1-13. doi: 10.1016/J.CPA.2008.09.009

Bache I, Bartle I, Flinders M, Marsden G (2015) Blame Games and Climate Change: Accountability, Multi-Level Governance and Carbon Management. Br J Polit Int Relations 17:64-88. doi: 10.1111/1467-856X.12040

Bäckstrand K (2008) Accountability of Networked Climate Governance: The Rise of Transnational Climate Partnerships. Glob Environ Polit 8:74-102. doi: 10.1162/glep.2008.8.3.74

Baird, J. et al. (2014) 'Learning effects of interactive decision-making processes for climate change adaptation', Global Environmental Change. Pergamon, 27, pp. 51-63. doi: 10.1016/J.GLOENVCHA.2014.04.019.

Behnam M, MacLean TL (2011) Where Is the Accountability in International Accountability Standards?: A Decoupling Perspective. Bus Ethics Q 21:45-72. doi: 10.5840/beq20112113

Bernstein, Steven. 2004. "Legitimacy in global environmental governance." J. Int'I L \& Int'I Rel. 1:139.

Betzold, Carola, Thomas Bernauer, and Vally Koubi. 2016. "Press Briefings in International Climate Change Negotiations." Environmental Communication-A Journal Of Nature and Culture 10 (5):575592. doi: 10.1080/17524032.2015.1094100.

Biermann, F. and Gupta, A. (2011) 'Accountability and legitimacy in earth system governance: A research framework', Ecological Economics. Elsevier, 70(11), pp. 1856-1864. doi: 10.1016/j.ecolecon.2011.04.008.

Biermann, F. et al. (2009) Earth System Governance: People, Places and the Planet. Science and Implementation Plan of the Earth System Governance Project, Governance An International Journal Of Policy And Administration. doi: 10.1787/9789264203419-101-en.

Biermann, F. et al. (2012) 'Transforming governance and institutions for global sustainability: key insights from the Earth System Governance Project', Current Opinion in Environmental Sustainability. Elsevier, 4(1), pp. 51-60. doi: 10.1016/J.COSUST.2012.01.014.

Blair, H. (2000) 'Participation and Accountability at the Periphery: Democratic Local Governance in Six Countries', World Development. Pergamon, 28(1), pp. 21-39. doi: 10.1016/S0305750X(99)00109-6.

Bovaird, T. (2005) 'Public governance: balancing stakeholder power in a network society', International Review of Administrative Sciences. Sage PublicationsSage CA: Thousand Oaks, CA, 71(2), pp. 217-228. doi: 10.1177/0020852305053881. 
Bovens, M., Schillemans, T. and Hart, P. T. (2008) 'Does public accountability work? An assessment tool', Public Administration. John Wiley \& Sons, Ltd (10.1111), 86(1), pp. 225-242. doi: 10.1111/j.1467-9299.2008.00716.x.

Bovens, M. (2014). Two Concepts of Accountability: Accountability as a Virtue and as a Mechanism. In Accountability and European Governance (pp. 28-49). Routledge.

Brink, E. and Wamsler, C. (2018) 'Collaborative Governance for Climate Change Adaptation: Mapping citizen-municipality interactions', Environmental Policy and Governance. John Wiley \& Sons, Ltd, 28(2), pp. 82-97. doi: 10.1002/eet.1795.

Broadbent, J., \& Laughlin, R. (2003). Public private partnerships: an introduction. Accounting, Auditing \& Accountability Journal, 16(3), 332-341.Carlsson, Ingvar, Shridath Ramphal, Ali Alatas, and Hans Dahlgren. 1995. Our global neighbourhood: The report of the commission on global governance: Oxford University Press Oxford.

Chan, Sander, and Philipp Pattberg. 2008. "Private rule-making and the politics of accountability: Analyzing global forest governance." Global Environmental Politics 8 (3):103-+. doi: DOI 10.1162/glep.2008.8.3.103.

Clare, Shari, Naomi Krogman, and Ken J. Caine. 2013. "The "balance discourse": A case study of power and wetland management." Geoforum 49:40-49. doi:

https://doi.org/10.1016/j.geoforum.2013.05.007.

Considine, M. (2002) 'The End of the Line? Accountable Governance in the Age of Networks, Partnerships, and Joined-Up Services', Governance. John Wiley \& Sons, Ltd (10.1111), 15(1), pp. 2140. doi: 10.1111/1468-0491.00178.

Demirag I, Dubnick M, Khadaroo M A (2004) Framework for Examining Accountability and Value for Money in the UK's Private Finance Initiative.

den Hond, Frank, Frank G. A. de Bakker, and Jonathan Doh. 2012. "What Prompts Companies to Collaboration With NGOs? Recent Evidence From the Netherlands." Business \& Society 54 (2):187228. doi: $10.1177 / 0007650312439549$.

Dingwerth, Klaus, and Philipp Pattberg. 2009. "World Politics and Organizational Fields: The Case of Transnational Sustainability Governance." European Journal of International Relations 15 (4):707743. doi: $10.1177 / 1354066109345056$.

Dingwerth, Klaus. 2005. "The democratic legitimacy of public-private rule making: What can we learn from the World Commission on Dams?" Global Governance: A Review of Multilateralism and International Organizations 11 (1):65-83.

Dingwerth, Klaus. 2007. The new transnationalism: Transnational governance and democratic legitimacy: Springer.

Dryzek, J. S. and Stevenson, H. (2011) 'Global democracy and earth system governance', Ecological Economics. Elsevier, 70(11), pp. 1865-1874. doi: 10.1016/J.ECOLECON.2011.01.021. 
Dunlop, Tessa, and Esteve Corbera. 2016. "Incentivizing REDD plus : How developing countries are laying the groundwork for benefit-sharing." Environmental Science \& Policy 63:44-54. doi: 10.1016/j.envsci.2016.04.018.

Falkner R (2003) Private Environmental Governance and International Relations: Exploring the Links. Glob Environ Polit 3:72-87. doi: 10.1162/152638003322068227

Few, R., Brown, K. and Tompkins, E. L. (2011) 'Public participation and climate change adaptation: avoiding the illusion of inclusion', Climate Policy. Taylor \& Francis Group. Available at: http://www.tandfonline.com/doi/abs/10.1080/14693062.2007.9685637 (Accessed: 6 June 2016).

Florini, Ann. 2007. The right to know : transparency for an open world / Ann Florini, editor foreword by Joseph E. Stiglitz. New York: New York : Columbia University Press.

Foley, J. A. et al. (2005) 'Global consequences of land use.', Science (New York, N.Y.), 309(5734), pp. 570-4. doi: 10.1126/science.1111772.

Fuchs, Doris, Agni Kalfagianni, and Tetty Havinga. 2011. "Actors in private food governance: the legitimacy of retail standards and multistakeholder initiatives with civil society participation." Agriculture and Human Values 28 (3):353-367. doi: 10.1007/s10460-009-9236-3.

Gellers, Joshua C. 2016. "Crowdsourcing global governance: sustainable development goals, civil society, and the pursuit of democratic legitimacy." International Environmental Agreements-Politics Law and Economics 16 (3):415-432. doi: 10.1007/s10784-016-9322-0.

Gilbert DU, Rasche A, Waddock S (2011) Accountability in a Global Economy: The Emergence of International Accountability Standards. Bus Ethics Q 21:23-44. doi: 10.5840/beq20112112

Godfrey Paul, C., B. Merrill Craig, and M. Hansen Jared. 2008. "The relationship between corporate social responsibility and shareholder value: an empirical test of the risk management hypothesis." Strategic Management Journal 30 (4):425-445. doi: 10.1002/smj.750.

Gordon, David J. 2016. "The Politics of Accountability in Networked Urban Climate Governance." Global Environmental Politics 16 (2):82-100. doi: 10.1162/GLEP_a_00357.

Grant, Ruth W., and Robert O. Keohane. 2005. "Accountability and Abuses of Power in World Politics." American Political Science Review null (01):29-43. doi: 10.1017.S0003055405051476.

Gulbrandsen, L. H., and G. Auld. 2016. "Contested Accountability Logics in Evolving Nonstate Certification for Fisheries Sustainability." Global Environmental Politics 16 (2):42-60. doi: 10.1162/GLEP_a_00353.

Gulbrandsen, Lars H. 2008. "Accountability arrangements in non-state standards organizations: instrumental design and imitation." Organization 15 (4):563-583.

Gunningham, Neil, A. Kagan Robert, and Dorothy Thornton. 2006. "Social License and Environmental Protection: Why Businesses Go Beyond Compliance." Law \& Social Inquiry 29 (2):307-341. doi: 10.1111/j.1747-4469.2004.tb00338.x. 
Gupta, A. (2008) 'Transparency Under Scrutiny: Information Disclosure in Global Environmental Governance', Global Environmental Politics. MIT Press 238 Main St., Suite 500, Cambridge, MA 02142-1046 USA journals-info@mit.edu ,8(2), pp. 1-7. doi: 10.1162/glep.2008.8.2.1.

Gupta, A. 2010. Transparency in global environmental governance: a coming of age? : MIT Press.

Held, D. (1991) 'Democracy, the nation-state and the global system', Economy and Society.

Routledge , 20(2), pp. 138-172. doi: 10.1080/03085149100000007.

Held, David. 1999. "The transformation of political community: rethinking democracy in the context of globalization." Democracy's edges:84-111.

Jamali D (2010) MNCs and International Accountability Standards Through an Institutional Lens: Evidence of Symbolic Conformity or Decoupling. J Bus Ethics 95:617-640. doi: 10.1007/s10551-0100443-z

Jedd, T. and Bixler, R. P. (2015) 'Accountability in Networked Governance: Learning from a case of landscape-scale forest conservation', Environmental Policy and Governance. John Wiley \& Sons, Ltd, 25(3), pp. 172-187. doi: 10.1002/eet.1670.

Jodoin, Sebastien, Sebastien Duyck, and Katherine Lofts. 2015. "Public Participation and Climate Governance: An Introduction." Review Of European Comparative \& International Environmental Law 24 (2):117-122. doi: 10.1111/reel.12126.

Keohane, R. O. (2003). Global governance and democratic accountability (pp. 130-159).

Kolhoff, Arend J., Hens A. C. Runhaar, Tamar Gugushvili, Gabi Sonderegger, Bart Van der Leest, and Peter P. J. Driessen. 2016. "The influence of actor capacities on ElA system performance in low and middle income countries -Cases from Georgia and Ghana." Environmental Impact Assessment Review 57:167-177. doi: 10.1016/j.eiar.2015.11.011.

Kramarz, T., and S. Park. 2016. "Accountability in Global Environmental Governance: A Meaningful Tool for Action?" Global Environmental Politics 16 (2):1-21. doi: 10.1162/GLEP_a_00349.

Kramarz, Teresa, and Bessma Momani. 2013. "The World Bank as Knowledge Bank: Analyzing the Limits of a Legitimate Global Knowledge Actor." Review Of Policy Research 30 (4):409-431. doi: 10.1111/ropr.12028.

Kramarz, Teresa. 2016. "World Bank Partnerships and the Promise of Democratic Governance." Environmental Policy and Governance 26 (1):3-15. doi: 10.1002/eet.1696.

Kunseler, Eva-Maria, Willemijn Tuinstra, Eleftheria Vasileiadou, and Arthur C. Petersen. 2015. "The reflective futures practitioner: Balancing salience, credibility and legitimacy in generating foresight knowledge with stakeholders." Futures 66:1-12. doi: 10.1016/j.futures.2014.10.006.

Leach, M. 2013. "Democracy in the anthropocene." Science and sustainable develop-ment goals at the UN. Huffington Post.

Leach, William D. 2006. "Collaborative public management and democracy: Evidence from western watershed partnerships." Public administration review 66:100-110. 
Lövbrand, E., Stripple, J. and Wiman, B. (2009) 'Earth System governmentality: Reflections on science in the Anthropocene', Global Environmental Change. Pergamon, 19(1), pp. 7-13. doi: 10.1016/J.GLOENVCHA.2008.10.002.

Mac Chapin, A. 2004. "Challenge to Conservationists. Can We Protect Natural Habitats without Abusing the People who Live in Them?'." World Watch 17:7-31.

Mason, Michael. 2008. "The Governance of Transnational Environmental Harm: Addressing New Modes of Accountability/Responsibility." Global Environmental Politics 8 (3):8-24. doi: 10.1162/glep.2008.8.3.8.

Mees, H. and Driessen, P. (2018) 'A framework for assessing the accountability of local governance arrangements for adaptation to climate change', Journal of Environmental Planning and Management. Routledge, pp. 1-21. doi: 10.1080/09640568.2018.1428184.

Miller, C. A. (2007) 'Democratization, international knowledge institutions, and global governance', Governance. Wiley/Blackwell (10.1111), 20(2), pp. 325-357. doi: 10.1111/j.1468-0491.2007.00359.x.

Obani, Pedi, and Joyeeta Gupta. 2016. "Human right to sanitation in the legal and non-legal literature: the need for greater synergy." Wiley Interdisciplinary Reviews-Water 3 (5):678-691. doi: 10.1002/wat2.1162.

Okereke, Chukwumerije, and Philip Coventry. 2016. "Climate justice and the international regime: before, during, and after Paris." Wiley Interdisciplinary Reviews-Climate Change 7 (6):834-851. doi: 10.1002/wcc.419.

Papadopoulos, Y. (2003) 'Cooperative forms of governance: Problems of democratic accountability in complex environments', European Journal of Political Research. John Wiley \& Sons, Ltd (10.1111), pp. 473-501. doi: 10.1111/1475-6765.00093.

Papadopoulos, Y. (2007) 'Problems of Democratic Accountability in Network and Multilevel Governance', European Law Journal. John Wiley \& Sons, Ltd (10.1111), 13(4), pp. 469-486. doi: 10.1111/j.1468-0386.2007.00379.x.

Papadopoulos, Y. (2014) 'Accountability and Multi-level Governance: More Accountability, Less Democracy?' Routledge, pp. 112-131. doi: 10.4324/9781315879390-11.

Radaelli, C. M. (2003) The Open Method of Coordination: A new governance architecture for the European Union? Available at:

https://ore.exeter.ac.uk/repository/bitstream/handle/10036/22489/Radaelli open

Method.pdf?sequence=2 (Accessed: 19 December 2018).

Rasche A (2009) Toward a model to compare and analyze accountability standards - the case of the UN Global Compact. Corp Soc Responsib Environ Manag 16:192-205. doi: 10.1002/csr.202

Reid, W. V et al. (2010) 'Earth System Science for Global', science.sciencemag.org, (April 2016), pp. 1-3. doi: 10.1126/science.1196263. 
Rietveld, P. et al. (2013) 'Towards Adaptive Spatial Planning for Climate Change: Balancing Between Robustness and Flexibility', Journal for European Environmental \& Planning Law, 10(1), pp. 29-53. doi: 10.1163/18760104-01001003.

Scherer AG, Palazzo G, Baumann D (2006) Global Rules and Private Actors: Toward a New Role of the Transnational Corporation in Global Governance. Bus Ethics Q 16:505-532. doi: 10.5840/beq200616446

Scherer AG, Palazzo G, Baumann D (2006) Global Rules and Private Actors: Toward a New Role of the Transnational Corporation in Global Governance. Bus Ethics Q 16:505-532. doi: 10.5840/beq200616446

Scobie, Michelle. 2017. "Accountability in climate change governance and Caribbean SIDS." Environment, Development and Sustainability 20 (2):769-787. doi: 10.1007/s10668-017-9909-9.

South Centre. 1997. For a strong and democratic United Nations : a South perspective on UN reform / South Centre. London

Spiro, Peter J. 1988. The Washington Quarterly 11 (null):191.

Spiro, Peter J. 1995. "New global communities: Nongovernmental organizations in international decision making institutions." The Washington Quarterly 18 (1):45-56. doi:

10.1080/01636609509550131.

Steffek, J. and Ferretti, M. P. (2009) 'Accountability or "Good Decisions"? The Competing Goals of Civil Society Participation in International Governance', Global Society. Routledge , 23(1), pp. 37-57. doi: 10.1080/13600820802556736.

Steffek, J., 2010. Public Accountability and the Public Sphere of International Governance. Ethics \& International Affairs, 24(1), pp.45-68. Available at: http://doi.wiley.com/10.1111/j.17477093.2010.00243.x [Accessed October 17, 2018].

Thaler, Thomas, and Meike Leuin-Keitel. 2016. "Multi-level stakeholder engagement in flood risk management-A question of roles and power: Lessons from England." Environmental Science \& Policy 55:292-301. doi: 10.1016/j.envsci.2015.04.007.

Torfing, J. et al. (2012) Interactive governance: Advancing the paradigm. Available at: https://books.google.com/books?hl=en\&lr=\&id=mgLIheNnyX8C\&oi=fnd\&pg=PP1\&ots=3Y0AlqZZh9\& sig=bnynxfKkG-ndetmBHvP-RQ_LI-4 (Accessed: 18 December 2018).

Vink, M. J., Dewulf, A. R. P. J. and Termeer, C. J. A. M. (2013) 'the Role of Knowledge and Power in Climate Change Adaptation', Ecology and Society, pp. 1-25. Available at: https://www.jstor.org/stable/26269416 (Accessed: 18 December 2018).

Werners SE, Flachner Z, Matczak P, et al (2009) Exploring earth system governance: A case study of floodplain management along the Tisza river in Hungary. Glob Environ Chang 19:503-511. doi: 10.1016/j.gloenvcha.2009.07.003 
Widerberg, Oscar, and Johannes Stripple. 2016. "The expanding field of cooperative initiatives for decarbonization: a review of five databases." Wiley Interdisciplinary Reviews-Climate Change 7 (4):486-500. doi: 10.1002/wcc.396.

Willer, David, Michael Lovaglia, and Barry Markovsky. 1997. "Power and influence: A theoretical bridge." Social Forces 76 (2):571-603. doi: 10.1093/sf/76.2.571.

Yengoh, Genesis Tambang, Karin Steen, Frederick Ato Armah, and Barry Ness. 2016. "Factors of vulnerability: How large-scale land acquisitions take advantage of local and national weaknesses in Sierra Leone." Land Use Policy 50:328-340. doi: 10.1016/j.landusepol.2015.09.028.

Young, Juliette C., Kate Searle, Adam Butler, Peter Simmons, Allan D. Watt, and Andrew Jordan. 2016. "The role of trust in the resolution of conservation conflicts." Biological Conservation. 